\title{
Review on factors affecting the optical properties of dental zirconia
}

\author{
Chan-Ho Park, Kyung-Ho Ko, Chan-Jin Park, Lee-Ra Cho, Yoon-Hyuk Huh* \\ Department of Prosthodontics and Research Institute of Oral Science, College of Dentistry, Gangneung-Wonju National University, \\ Gangneung, Republic of Korea
}

Clinical applications of translucent zirconia as well as traditional zirconia ( $3 \mathrm{~mol} \%$ yttria stabilized tetragonal zirconia polycrystal, 3Y-TZP) are increasing. For this reason, studies on factors affecting the optical properties of dental zirconia have been continuously reported. The optical effect of dental zirconia may vary depending on the yttria content, the thickness of the prosthesis, the sintering process, polishing, glazing and cementation in laboratory and clinical procedures. Increasing the yttria concentration can reduce the masking effect. Translucency decreases as the thickness of the restoration increases, but the required thickness may vary depending on the properties of the zirconia block. The high-speed sintering method can shorten the manufacturing time, but in some cases, the translucency of the prosthesis may decrease. In addition, the optical properties can be affected by the surface roughness of zirconia and the polishing process. The use of an appropriate colored cement can help with the masking effect of zirconia and can be useful for color matching for more esthetic results. (J Dent Rehabil Appl Sci 2021;37(4):177-85)

Key words: zirconia; tanslucency parameter; yttria; sintering; glazing; polishing

\begin{abstract}
서론
이트리아(yttrium oxide)로 안정화된 정방정 지르코니 아(3 mol\% yttria stabilized tetragonal zirconia polycrystal, $3 \mathrm{Y}-\mathrm{TZP}$ )가 치과용 세라믹 신소재로 사용되고 있으 나 불투명한 비미심적 수복물이 단점으로 지적되었다 (Fig. 1). ${ }^{1}$ 이후 알루미나 함량을 감소시킨(2세대) 지르코 니아와 이트리아 비율을 증가시킨(3세대) 지르코니아 개 발 등 반투명도를 증가시켜 광학적 성질을 개선하기 위 한 다양한 시도가 이루어지고 있다., 반투명 지르코니 아(translucent zirconia)의 색조에 가장 큰 영향을 미치 는 것은 이트리아 함량 증가이지만 그 외에도 수복물의 두께, 소결(sintering)과정, 광택소성(glazing), 표면 연마 및 시멘트 종류 등 다양한 요인들도 실제 임상에서 지르 코니아 보철물의 색조에 영향을 미칠 수 있다. ${ }^{4-6}$ 이트리
\end{abstract}

\footnotetext{
*Correspondence to: Yoon-Hyuk Huh

Associate Professor, Department of Prosthodontics and Research Institute of

Oral Science, College of Dentistry, Gangneung-Wonju National University,

7 Jukheon-gil, Gangneung, 25457, Republic of Korea

Tel: +82-33-640-2758, Fax: +82-33-640-3103, E-mail: vino@gwnu.ac.kr

Received: October 18, 2021/Last Revision: October 25, 2021/Accepted: October

27,2021
}
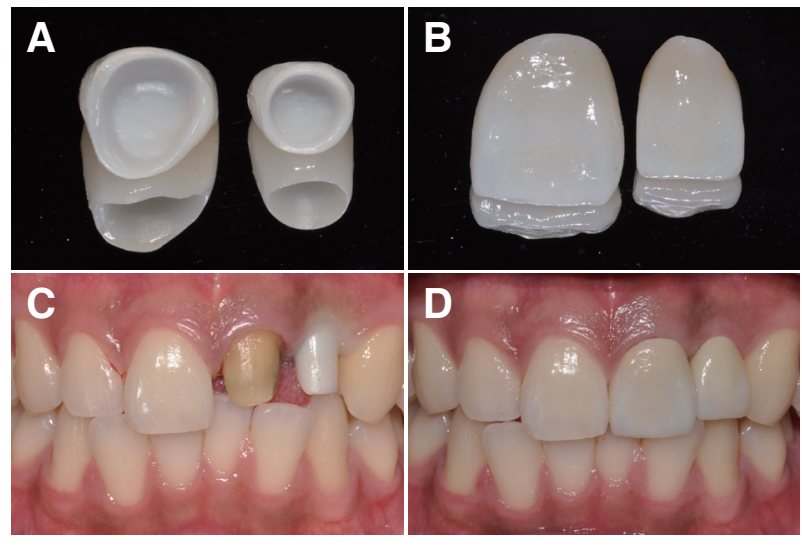

Fig. 1. Opacity and masking effect of monolithic zirconia crowns. (A) Internal lab view, (B) Labial lab view, (C) Discolored maxillary left central incisor and zirconia implant abutment on maxillary left lateral incisor, (D) Definite restoration.

Copyright $\bigcirc 2021$ The Korean Academy of Stomatognathic Function and Occlusion. (c) It is identical to Creative Commons Non-Commercial License. 
아 함량이 증가된 반투명 지르코니아는 입방정상(cubic phase)이 증가하고 소결온도가 올라가면서 지르코니 아 결정크기가 증가하게 되어 전통적인 지르코니아(3YTZP)보다 더 낮은 파절저항성을 보인다. ${ }^{5}$ 따라서 반투명 지르코니아의 기계적 성질 저하를 고려한 수복물의 두께 및 형태 부여가 필요하고 소결과정에서도 기계적 성질 저 하를 방지하기 위해 유의해야 하는데 이러한 과정 자체 가 전반적으로 색조에 영향을 줄 수 있다. 반투명 지르코 니아이므로 접착 과정에서 시멘트의 종류와 색조에 따라 구강 내 최종접착한 보철물의 색조 차이가 발생할 가능 성도 배제할 수 없다. 이에 본 문헌고찰에서는 지르코니 아의 색조에 영향을 미치는 다양한 요소들에 관한 논문 헌을 살펴봄으로써 기공 및 임상과정에서 지르코니아를 이용한 보철치료 시 고려해야할 사항들에 대해 살펴보고 자 한다.

\section{문헌고찰}

\section{색조 차이 판별 지표}

지르코니아의 광학적 성질에 영향을 미치는 요소를 이해하기에 앞서 목표 색조와 수복물의 색조 차이는 어 떤 식으로 정량화되는지 알아 볼 필요가 있다. 현재 치과 재료의 색상에 관해서는 국제조명위원회(International Commission on I'llumination, CIE)에서 지정한 지표를 많이 사용하는데, CIELAB 색도계 좌표를 근간으로 하 는 $\operatorname{CIE} 76\left(\Delta E^{*}{ }_{a b}\right)$ 이 최초의 공식이다. 그러나 색차식 값 과 실제 지각되는 색상간의 불일치, 즉 지각적 불균일성 을 개선하기 위해 CIE는 수 년에 걸쳐 정의를 구체화해 왔다. 많은 색조실험에서는 여전히 $\operatorname{CIE} 76\left(\Delta E^{*}{ }_{a b}\right)$ 이 사용 되고 있으나 CIE는 인지색상(perceived color)과 계산된 (computed) 색조 차이 간의 보정을 위해 $\mathrm{S}_{\mathrm{L}}$ (명도 가중함 수), $\mathrm{S}_{\mathrm{C}}$ (채도 가중함수), $\mathrm{S}_{\mathrm{H}}$ (색상 가중함수), $\mathrm{R}_{\mathrm{T}}$ (푸른색 영역에서 채도차와 색상차 사이의 상호작용 요소) 등의 함수를 통해 보완한 식인 CIEDE2000 $\left(\Delta E^{*}{ }_{00}\right)$ 의 사용을 권장하고 있다. ${ }^{7}$ 두 지표를 도출하는 식은 다음과 같다.

$$
\triangle E^{*}{ }_{a b}=\sqrt{\left(L^{*}{ }_{2}-L^{*}{ }_{1}\right)^{2}+\left(a^{*}{ }_{2}-a^{*}{ }_{1}\right)^{2}+\left(b^{*}{ }_{2}-b^{*}{ }_{1}\right)^{2}} \ldots(\mathrm{CIE76})
$$

$L_{2}^{*}-L^{*}{ }_{1}(\Delta L)$ : lightness difference between the sample $a_{2}^{*} a_{2} a_{1}$ : redness or greyness difference between the sample $b_{2}^{*}{ }_{2}-b_{1}^{*}$ : blueness-yellowness difference between the sample

$$
\begin{aligned}
\Delta E^{*}{ }_{00}= & \sqrt{\left(\frac{\Delta L^{\prime}}{k_{L} S_{L}}\right)^{2}+\left(\frac{\Delta C^{\prime}}{k_{C} S_{C}}\right)^{2}+\left(\frac{\Delta H^{\prime}}{k_{H} S_{H}}\right)^{2}+R_{T} \frac{\Delta C^{\prime}}{k_{C} S_{C}} \frac{\Delta H^{\prime}}{k_{H} S_{H}}} \\
& \ldots(\text { CIEDE2000) }
\end{aligned}
$$

$\Delta L^{\prime}=$ Lightness difference, $C^{\prime}=$ Chroma difference, $\Delta H^{\prime}=$ Hue difference

$S_{L}=$ Compensation for lightness, $S_{C}=$ Compensation for chroma, $S_{H}=$ Compensation for hue $k_{L}, k_{O} k_{H}=$ Parametric coefficients, $\mathrm{R}_{T}=$ Hue rotation term

치과용 세라믹의 시각적 성질을 평가하는 지표로는 투 과도(transmittance), 반투명도(tanslucency parameter, $\mathrm{TP})$ 및 명암비(contrast ratio, CR) 등을 이용한다. 투과 도는 특정 파장에서 투과되는 빛의 양으로, 투과하기 전 과 투과한 후의 빛의 양의 비율을 \%로 표기한다. 반투명 도와 명암비는 각각 흰색과 검은색 배경을 놓고 시편에 서 반사된 빛으로 측정하며 공식에 대입하여 얻는 절댓 값으로 표현한다. 세 가지 변수 중 투과도는 특정 파장 에서의 흡수되는 정도만 반영하기 때문에 광원이 바뀌는 여러 상황을 재현하지 못하고, 흡수되는 정도를 사람의 눈이 어느 정도로 인지하는지를 모른다는 단점이 있다. ${ }^{8}$ 반투명도와 명암비는 인간이 받아들이는 반사광을 사용 하며 인간의 색 인지와 거의 같은 CIE 색도계를 사용한 다는 장점이 있어 임상상황을 더 잘 반영한다고 할 수 있 으며 기존의 연구들도 대부분 이 두 가지를 사용하는데, 이 중 임상상황과 더 유사한 반투명도가 세라믹의 광학 적 성질을 평가하는 실험에 가장 일반적으로 사용되는 지표이다(Fig. 2). ${ }^{8-11}$

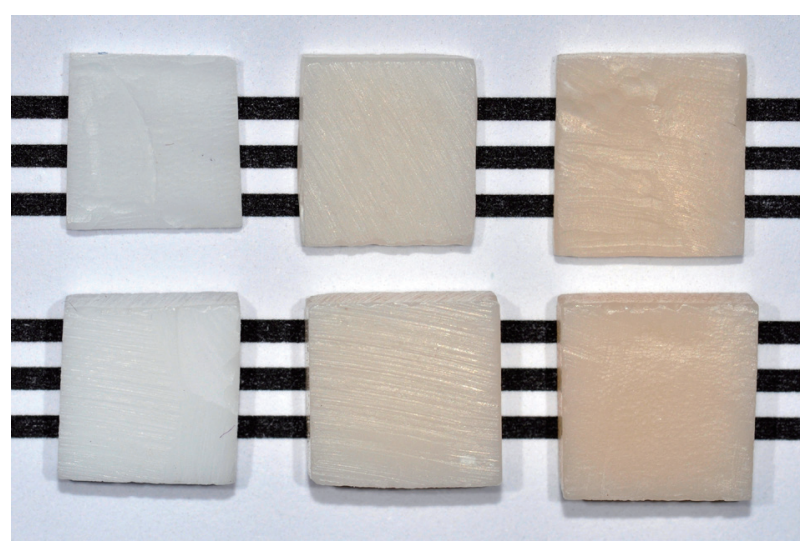

Fig. 2. Translucency parameter test. Appearance of monolithic zirconia specimens, Zenostar TO (TO) (left column), Zenostar sun (Ts) (middle column), and Zenostar sun chroma (Tsc) (right column). Thickness of upper row is $1 \mathrm{~mm}$ and lower row is $3 \mathrm{~mm}$. 
색조차이가 어느 정도인지 판단하는 것도 중요한데, 지각임계값(perceptibility threshold, PT) 및 허용임계값 (acceptability threshold, AT)을 기준으로 치과용 세라믹 재료를 선택하고 임상 성능평가에 이용한다. 지각임계값 은 관찰한 사람 중 $50 \%$ 가 인지하는 색차이를 말하며 허 용임계값은 마찬가지로 $50 \%$ 의 관찰자가 임상적으로 허 용 가능하다고 판단하는 색차이를 나타낸다. Vichi 등 ${ }^{\circ}$ 은 $\Delta E^{*}{ }_{a b}$ 가 1 미만일 경우 색차이를 지각할 수 없으며, 1 과 3 사이에서는 임상적으로 허용될 만한데, 3을 넘을 경우 임 상적으로 받아들일 수 없다고 하였다. 복합레진을 이용 하여 얻은 이 결과값은 실험재료와 상관없이 많은 문헌 에서 인용되고 있다. 한편 Paravina 등른 세라믹 시편을 이용한 실험에서 $\Delta E^{*}{ }_{a b}$ 로 계산한 지각임계값과 허용임계 값은 각각 1.2 와 2.7 이며 $\Delta E^{*}{ }_{00}$ 로 계산한 지각임계값 및 허용임계값은 각 0.8 과 1.8 이라고 하였다. 이렇듯 재료에 따라서도 색차이 임계값은 다를 수 있으므로 임상가는 이를 인지하고 실험에서 얻은 결과값을 객관적으로 해석 할 수 있어야 한다.

\section{지르코니아의 광학적 성질에 영향을 미치는 요소}

지르코니아 블록은 밀링(milling)이 용이하도록 일반적 으로 예비소결(pre-sintered) 상태로 제공되며 제조사에 따라 구성성분, 입자크기(grain size) 등을 달리하여 물리 적, 광학적 특징을 조절하고 변화를 준다. 기공실에서는 원하는 수복물 형태로 밀링을 시행하며 이 때 수복물은 최종수복물보다 $20-25 \%$ 정도 큰 상태로 가공한다. 색 조절을 위해 사용하는 색용액(coloring liquid)은 제조사 에 따라 적용방법 및 색상이 다양하다. 최종소결을 거치 면 수복물은 $20-25 \%$ 의 부피 수축이 발생하여 최종밀도 에 도달하게 되고 물리적, 광학적 성질의 변화가 일어난 다. 이후에 최종적인 연마 및 마무리 과정이 이루어지며 이 때 추가적인 착색(staining)이나 광택소성을 시행한다.

Table 1. Factors affecting the shade of zirconia prosthesis by manufacturing process

\begin{tabular}{ll}
\hline \multicolumn{1}{c}{ Manufacturing process } & \multicolumn{1}{c}{ Affecting factors } \\
\hline Zirconia block fabrication & Yttria contents \\
Design and milling & Thickness \\
Sintering & Sintering time, speed \\
Finishing & Polishing and glazing \\
Prosthesis placement & Cement shade \\
\hline
\end{tabular}

지르코니아 수복물의 제작과정 중 광학적 성질에 영향을 미치는 요소들에 대해 자세히 살펴 보겠다(Table 1).

3Y-TZP에서 이트리아농도를 4 - $5 \mathrm{~mol} \%$ 까지 높이면 상온에서 입방정상 비율이 증가하므로 입자의 경계에서 발생하는 복굴절(birefringence) 발생을 저지하여 반투 명도를 높일 수 있으나 굴곡강도 등의 기계적 성질 저하 로 인해 첨가비율을 무한히 증가시킬 수는 없다. Sen과 $\mathrm{Isler}^{13}$ 은 이트리아 함량을 증가시킨 지르코니아는 반투 명도가 증가하고 명암비가 감소한다고 하였다. Cho 등 ${ }^{14}$ 은 우수한 반투명도를 가져 심미수복에 자주 쓰이는 리 튬 디실리케이트 유리 도재와 이트리아 함량이 다양한 지르코니아의 반투명도를 비교하였다. 두께와 상관없이 리튬 디실리케이트의 반투명도가 가장 높았고 5Y-PSZ (5 mol\% yttria partially stabilized zirconia), 4Y-PSZ (4 mol\% yttria partially stabilized zirconia), 3Y-TZP 순으 로 반투명도가 높았으며, 5Y-PSZ의 반투명도는 리튬 디 실리케이트와 비교하여 약 $80 \%$ 의 반투명도를 나타낸다 고 하였다. 한편 이트리아 농도별 지르코니아와 리튬 디 실리케이트의 반투명도 비교에 대해서는 저자들마다 다 른 결과를 보고하기도 한다. $\mathrm{Kim}^{15}$ 는 이트리아 농도를 높이면 반투명도가 증가하기는 하지만, 리튬 디실리케이 트 결정화 유리도재나 소의 영구치(bovine incisors)에 비 해서는 낮다고 보고하여 Cho 등 ${ }^{14}$ 과 의견을 같이 한다. 반면 Baldissara 등 ${ }^{11}$ 은 리튬 디실리케이트가 5Y-PSZ 시 편에 비해 반투명도가 낮다는 상반된 보고를 하였다. 저 자는 다른 연구와 달리 크라운 형태로 시편을 제작하여 빛의 산란 및 반사를 실제 임상상황과 유사하게 재현할 수 있었기 때문에 이 연구의 결과에 대한 합리성을 주장 하였다. 또한 $460 \mathrm{~nm}$ 의 백색광을 사용하여 측정한 것이 지르코니아의 반투명도 값이 높게 나타난 원인이라고 설 명하였으며 이는 낮은 파장의 빛에서 높은 파장 하에서 측정한 것보다 지르코니아의 반투명도가 높다고 한 $\mathrm{Ha}-$ $\mathrm{rada}$ 등 $^{10}$ 의 연구결과와도 유사하다. 이상과 같이 이트리 아 농도를 높인 지르코니아의 우수한 반투명도를 다시 확인할 수 있으나, 아직 리튬 디실리케이트보다는 심미성 에서 약점을 가지며, 색조평가 실험을 할 때는 가급적 임 상상황과 유사하게 표준화된 실험조건을 사용하는 것이 추천된다고 할 수 있다.

우수한 반투명도만이 심미적으로 우수한 재료를 평가 하는 척도로 이용되는 것은 아니며 지대치의 색을 적절히 차폐하는 능력 또한 중요한 요소이다. 배경(지대치 색상) 에 변화를 주어 지르코니아의 차폐능을 분석한 연구에서 
모든 지르코니아(3Y-TZP, 4Y-PSZ, 5Y-PSZ)가 일반 상 아질에 비해 우수한 차폐능을 보였지만 티타늄 및 변색 된 상아질 배경에서는 불량한 차폐능을 보였다. ${ }^{14}$ 따라서 지대치 상황에 따라 불투명한 지르코니아를 선택하는 것 이 더 심미적일 수도 있으므로 임상가는 지대치의 색조 를 판단하여 적절한 차폐능을 얻을 수 있는 지르코니아 블록을 선택할 수 있는 안목을 갖추어야 한다.

이상과 같은 연구를 종합하면, 이트리아 함량이 증가 할수록 반투명도가 증가하지만 명암비는 감소하며 그 결 과 차폐효과는 나빠지므로 결과적으로 수복 전 보철물 을 통해 얻으려고 했던 목표 색조와는 차이가 날 수 있 다. 따라서 임상가들은 단순히 이트리아 함량의 증가로 인한 반투명도 증가 효과 외에 지대치의 색조를 평가하 여 차폐능을 선택하고 보철물의 두께를 조절하여 원하는 보철물 색조를 얻을 수 있어야 한다.

파괴인성(fracture toughness) 관점에서 구치부 단일구 조 지르코니아의 교합면의 최소 두께는 $0.5 \mathrm{~mm}$ 이상으 로 알려져 있으나, ${ }^{16}$ 심미성을 위한 최소두께에 관한 기 준은 불명확하다. 수복물의 두께가 두꺼울수록 차폐능 은 증가하나 반투명도는 감소하므로 비심미적이라는 것 은 일반적으로 알려진 사실이다. 지르코니아의 두께가 $0.5 \mathrm{~mm}$ 에서 $1 \mathrm{~mm}$ 로 증가함에 따라 VLTP (visible light transmittance percentage)는 약 $10 \%$ 감소하는데, ${ }^{10}$ 이는 수복물의 작은 두께의 변화에도 반투명도가 크게 변화할 수 있음을 의미한다. 따라서 최종수복물의 두께를 염두 에 둔 주의 깊은 치아삭제가 필요하며, 심미보철을 계획 할 때는 수복공간에 대한 이해가 선행되어야 할 것이다.

Tabatabaian 등 $^{17}$ 은 시판 중인 두 종류의 A2 색조 반투 명 지르코니아 시편을 A4 색조의 배경과 중첩 후 기존 색 조(A2)와의 색차이 $(\Delta \mathrm{E})$ 에 대해서 실험한 결과 $0.9 \mathrm{~mm}$ 와 $1.1 \mathrm{~mm}$ 두께의 시편에 대해서는 허용임계값 이하의 색차이를, $0.7 \mathrm{~mm}$ 두께의 시편에 대해서는 허용임계값 을 넘는 색차이가 나타난다고 하였다. 후속 연구 ${ }^{18}$ 에서 는 허용임계값 이하의 색차이를 얻기 위해 $1.1 \mathrm{~mm}$ 의 수 복물 두께 확보가 필요하며 목표 색상과 배경과의 색차 이가 클수록 색상 불일치가 증가한다고 하였다. 즉, 수복 물 두께가 증가하면 차폐효과에는 도움이 되기는 하지만 근본적으로 지르코니아의 불균질 다결정 구조(inhomogeneous polycrystalline microstructure)는 균질한 장방 형의 수산화인회석 격자를 가진 법랑질과는 미세구조가 다르기 때문에 색상을 완전히 보상하기는 어렵다고 보았 다. 정리하면 고반투명 지르코니아에서 색상 일치를 얻기
위해서는 $1.1 \mathrm{~mm}$ 이상의 수복물 두께 확보가 필요하며 지대치 색조가 어두운 경우라면 시멘트를 이용한 추가적 보정효과가 필요할 수 있다는 것이다.

한편 수복물의 두께가 반투명도에 미치는 영향은 작 다고 평가되기도 하는데, Kang 등 ${ }^{19}$ 은 다층 지르코니아 (multilayered zirconia)의 색조를 비교한 연구에서 지르 코니아의 두께가 두꺼워질수록 반투명도(TP)가 낮아지 고 채도는 높아지며 $\Delta \mathrm{E}$ 가 감소하여 지르코니아의 차폐 효과가 증가한다고 하였다. 또한 상대적으로 높은 반투 명도를 보이는 블록을 낮은 반투명도의 블록과 비교한 결 과 지르코니아 블록 종류가 두께보다 최종색상에 더 큰 영향을 미친다고 하였다. 반투명도 차이에 있어 수복물의 두께보다 블록의 재료가 더 큰 영향을 미친다는 사실은 Sulaiman 등 $^{20}$ 및 Wang 등 ${ }^{21}$ 의 연구결과와도 일치한다.

정리하면 지르코니아 수복물의 두께가 증가할수록 반 투명도는 낮아지나 차폐효과가 증가하므로 목표색상과 의 색차이가 감소하는 장점이 있으므로 필요한 경우에는 시멘트의 차폐효과를 적절히 활용해야 한다. 또한 지르 코니아 블록 종류가 미치는 영향이 크므로 적절한 블록 을 선택하는 것이 중요하다.

고온에서의 소결 및 연장된 소결시간은 지르코니아의 입자크기를 증가시킴과 동시에 확산을 촉진시켜 기공 (pore) 분포를 감소시켜 반투명도를 증가시키며, 목표 색 상과의 색차이를 감소시키는 긍정적인 영향을 미치는 것 으로 알려져 있다. ${ }^{22,23}$

구강스캐너를 이용한 지르코니아 보철물의 당일 제작 이 가능해지면서 고속소결(high-speed sintering)에 대한 관심이 높아지고 있다. 기존의 전통적인 소결방법은 전류 를 이용하여 주변 공기를 가열하는 방식으로 가열속도가 분당 $5-10^{\circ} \mathrm{C}$ 로 제한적일 뿐만 아니라 수 시간의 소결시 간이 필요한 반면, 고속소결은 전자기 유도 및 자기장을 이용하여 분당 $50-100^{\circ} \mathrm{C}$ 의 현저하게 빠른 가열과정을 통해 소결완료까지 18 - 30분이면 충분하다. ${ }^{24}$ 다만, 이러 한 급격한 온도 증가를 동반한 소결과정은 지르코니아의 기계적 성질에 부정적인 영향을 미칠수 있으며 색조변화 를 유발할 수도 있다. ${ }^{16,17}$

Jansen 등 $^{25}$ 은 알루미나의 농도가 다른 $3 \mathrm{Y}-\mathrm{TZP}$ 를 대 상으로 소결방법이 색에 미치는 영향을 알아보기 위하여 라만분광법(Raman spectroscopy)을 이용한 분석을 시 행하였다. 고속소결에서도 단사정(monoclinic)상은 발견 되지 않았으며 이는 고속소결에서도 상이 안정화되어 있 음을 뜻한다. 높은 알루미나 농도의 $3 \mathrm{Y}-\mathrm{TZP}$ 의 경우 고 
속소결에서의 높은 온도와 짧은 소결시간으로 인해 입자 의 밀도가 높아졌지만 동시에 입자간 기공 공간이 작아 져 결과적으로 반투명도의 변화가 적었다고 하였다. 반 면 낮은 알루미나 농도의 $3 \mathrm{Y}-\mathrm{TZP}$ 의 경우 고온에서 알루 미나 입자의 확산 및 재배치 과정이 발생하고 그 결과 알 루미나가 결정 격자(crystal lattice) 사이에 균일하게 위 치하게 되어 지르코니아와 다른 굴절률을 보인다고 하였 다. 이렇게 서로 다른 굴절률이 존재하는 복굴절의 증가 는 반투명도를 감소시키는 결과를 초래한다. 지르코니아 의 이트리아 함량 및 알루미나 함량에 따라 고속소결이 반투명도에 미치는 영향이 달라지는 것이다.

앞의 논문이 3Y-TZP와 4Y-PSZ를 대상으로 실험하였 다면 Lawson과 Maharishi ${ }^{24}$ 는 3가지 종류의 5Y-PSZ 반 투명 지르코니아를 대상으로 고속소결에 따른 물성변화 를 비교하였다. Katana STML (Kuraray Noritake Dental Inc., Tokyo, Japan)에서는 소결방법에 따른 물리적 특성 의 유의한 변화가 없는 반면 다른 반투명 지르코니아에 서는 고속소결에서 입자크기 증가 및 반투명도의 감소가 관찰되었다. 즉 같은 $5 \mathrm{Y}-\mathrm{PSZ}$ 라도 재료에 따라 고속소결 에 따른 반투명도가 다른 결과를 보이게 되는 것이다.

정리하면 소결온도 증가 및 소결시간의 증가는 그 자 체로는 반투명도를 증가시키는 변수이지만 짧은 시간 동 안 급격히 소결온도를 증가시키는 고속소결방법이 반투 명도에 미치는 영향은 제품마다 다를 수 있다는 것이다. 따라서 전통적인 소결프로그램과 비교 시 고속 소결방법 은 지르코니아 입자크기의 증가를 유발하지만 동시에 반 투명도를 저해하는 현상이 혼재되는 양상을 보일 수 있 으므로 제조사의 권고사항을 준수하여 주의 깊게 적용하 는 것이 필요하다.

지르코니아의 표면은 다결정 구조를 가지고 있어 표면 거칠기가 증가함에 따라 산란효과로 인해 반투명도가 낮 아지고 심미성이 저하될 수 있으며, 거친 표면은 수복물 의 착색성(stainability)을 증가시켜 장기적인 색 안정성에 도 불리하다. ${ }^{26,27}$ 최종소결 후에 시행하는 광택소성 및 기 공실 혹은 진료실에서도 시행하는 표면연마는 수복물의 광택을 증가시키고 대합치의 마모를 감소시킬 뿐 아니라 치태축적을 감소시켜 치주건강을 유지하게 하는 중요한 과정이다. 다만 보철물이 부적절한 힘을 받아 표면 미세 파절(superficial microcracks)이 발행한 경우 정방정에서 단사정으로의 상변이가 일어나 불투명도가 증가할 수 있 으므로 주의 깊은 표면연마가 요구된다. ${ }^{28}$

광택소성을 시행한 후 $L^{*}$ 및 $a *$ 값의 증가하고 $\mathrm{b} *$ 값이
감소하여 $\Delta \mathrm{E}$ 가 증가하는 양상을 보고한 연구들에서는 29-31 그 원인으로 광택소성으로 인해 보다 활택해진 표 면에서 반사광이 증가하기 때문이라고 하였다. 그러나 $\mathrm{Kim}$ 등 $^{32}$ 의 연구에서는 광택소성 후 $\mathrm{L}^{*}$ 값이 감소한다고 하였는데, 이는 미리 착색처리된(precolored) 시편을 사 용한 Manziuc 등 ${ }^{30}$ 의 실험 방법과 달리 여러 겹의 착색액 을 사용했기 때문이라고 하였다. 따라서 세라믹에 착색 처리를 하는 방법에 따라 광택소성이 $\mathrm{L}^{*}$ 값의 변화에 미 치는 영향이 다를 수 있다. 한편 세라믹층과 상부의 광택 소성 층의 광학적 상호작용으로 설명되는 반투명도는 광 택소성에 의한 영향이 없는 것으로 나타났다. 또한 색 변 화는 반투명도보다 임상에서 더 조절하기 어렵기 때문에 주의를 기울여야 한다고 주장하였다.

$\mathrm{Huh}$ 등 $^{33}$ 은 두께가 다른 3종의 단일구조 지르코니아 를 대상으로 연마처리를 한 후 표면거칠기가 지르코니아 의 밝기 변화에 미치는 영향을 살펴보았다. 표면연마 후 표면거칠기는 유의하게 감소하였으며 명도도 감소하였 는데, 이러한 경향은 $1 \mathrm{~mm}$ 두께에서보다 빛의 불투과성 이 더 큰 $3 \mathrm{~mm}$ 두께의 시편에서 더 뚜렷하였으며 황색 또는 갈색 색조블록에서 밝은 색조 블록보다 더 뚜렷하 게 나타났다. 즉 불투명하고 거친 지르코니아 표면일수 록 빛의 난반사는 증가하고 그 결과 보다 높은 명도를 보 인다고 할 수 있다.

광택소성과 연마과정에 의한 활택한 지르코니아 표면 에서 Manziuc 등 ${ }^{30}$ 과 Saker와 Özcan ${ }^{31}$ 은 명도의 증가를 보고한 반면 Huh 등 $^{33}$ 은 오히려 명도가 감소한다고 하 였다. 이렇게 상반된 결과가 나타나는 한 원인은 반사광 의 측정방법이다. 정반사요소 포함방식(specular component included, SCI)은 물체의 표면상태를 고려하지 않으 며 정반사광까지 모두 측정한다. 반면, 정반사요소 제외 방식(specular component excluded, SCE)을 사용하면 정반사광은 측정에서 제외하며 부드러운 표면이 더 어둡 게 측정되는데, 이런 방식이 인간의 눈이 사물을 인식하 는 방식과 더 유사하다고 알려져 있다. 따라서 활택한 지 르코니아 표면에서는 정반사광이 증가하므로 이를 측정 에 포함한 경우 명도가 증가하나, 정반사광을 배재한 경 우 오히려 명도가 낮아지게 되는 것이다. 실제 임상에서 는 거친 표면의 지르코니아 보철물일 때 더 높은 명도를 가지다가 연마 후 명도가 감소되는 현상이 발생할 수 있 으므로 주의해야 한다.

한편 색을 측정하고자 하는 영역 외에서 발생하는 빛 의 산란이 결과값에 영향을 미치기도 한다. 모서리 손실 
(edge loss)은 광학장치의 노출영역을 넘어선 부분에서 빛이 산란될 때 심미적 수복재료의 반사율을 덜 측정하 는 현상을 말한다. 측정 반경(viewing aperture)에 따른 복합레진의 색차이를 실험한 Lee 등 ${ }^{34}$ 은 모서리 손실의 정도는 지형학적 형태(measuring geometry), 표면반사, 재료의 표면조건에 의해 영향을 받을 수 있다고 하였다. 따라서 심미재료의 색상을 정확하게 평가하기 위해서 적 절한 모서리 손실 수준을 결정하는 것이 선행되어야 한 다. 실험결과 SCI 방식으로 측정한 L*값은 SCE 방식으 로 측정했을 때보다 모두 높게 측정되었으며 측정반경의 차이에 따른 $\Delta \mathrm{E}$ 의 차이는 $\mathrm{SCE}$ 방식에서 더 크게 나타났 다. 이는 측정반경의 차이에 따른 반사율 차이를 모서리 손실의 정도로 생각했을 때 SCE 방식에서 재료의 광학 적 특성을 더 민감하게 측정하는 것으로 볼 수 있다. 즉 재료 자체의 광학적 특성을 연구하기 위함이라면 표면조 건과 관계없이 전체반사량을 측정하는 SCI 방식이 적절 하지만 실제 임상에서의 활용을 위한 연구라면 SCE 방 식이 더 적절하다고 할 수 있다.

이상과 같은 내용을 정리하면 광택소성 및 표면연마 후 표면거칠기는 감소하게 되고 실제 우리의 눈이 사물 을 인식하는 방식인 SCE 방법으로 측정 시 $\mathrm{L}^{*}$ 값은 감소, 즉 보철물은 어두운 색을 띄게 된다. 또한 색조를 연구하 려면 실제 임상과 가까운 정교한 실험방법 및 세심한 실 험조건 조절을 통해 임상적 의미를 전달할 수 있는 설계 가 필요하다.

합착은 임상과정 중 지르코니아 수복물의 광학적 성질 에 영향을 미칠 수 있는 마지막 과정이다. MDP (methacryloyloxydecyl dihydrogen phosphate) 기반 레진시멘트 가 다른 유형의 치과용 시멘트보다 더 높은 접착력을 나 타낸다는 사실은 널리 알려져 있다. ${ }^{35}$ 색조측정 기술의 발 전에도 불구하고 다양한 종류의 치과용 시멘트 중 특정 상황에 맞는 것을 선택하여 심미수복물을 접착하는 일은 임상가들에게는 늘 도전적인 과제다.

지대치 색조의 영향은 배제하고 레진시멘트, 레진강화 글라스아이노머(resin modified glass ionomer, RMGI) 시멘트, 글라스아이노머(glass ionomer, GI)시멘트를 단 일구조 지르코니아에 적용한 후 색변화를 비교한 실험에 서 치과용 시멘트의 종류는 최종보철물의 색조에 영향을 미쳤다. ${ }^{36}$ 수복물의 두께가 얇을수록 시멘트가 최종색조 에 더 큰 영향을 주며 레진강화글라스아이노머가 접착전 후의 색차이가 가장 작았다. 그러나 실험실 연구에서는 지대치 색상을 고려하지 않기 때문에 이러한 실험결과는
주의해서 받아들일 필요가 있다.

마찬가지로 지대치의 영향을 배제하였을 때 0.5-2 $\mathrm{mm}$ 의 반투명 지르코니아에서 불투명 레진시멘트는 투 명 레진시멘트에 비해 $\mathrm{L}^{*}, \mathrm{a}^{*}, \mathrm{~b}$ *값의 증가와 함께 $\Delta \mathrm{E}$ 의 증가를 유발하고 반투명도의 감소를 유발하였다. ${ }^{37}$

Tabatabaian 등 $^{38}$ 은 반투명 지르코니아(DDcube, Dental Direkt, Spenge, Germany)의 치과용 시멘트 색상에 따른 색 변화 실험을 A3.5 색상의 복합레진을 지대치 배 경으로 설정하여 시행하였다. 불투명 시멘트인 산화아연 시멘트와 인산아연시멘트로 접착한 시편에서 투명/반투 명 시멘트(레진시멘트와 GI시멘트)로 접착한 시편에 비 해 접착 전후의 색차이는 컸으나 최종색상과의 $\Delta \mathrm{E}$ 는 불 투명 시멘트 군에서만 1.8 이하의 허용가능한 수준으로 나타났다. 즉 고반투명 지르코니아 사용 시에는 치과용 시멘트의 차폐효과를 기대할 수 있는 불투명 시멘트를 사용하는 것이 바람직하며, 이는 저반투명 지르코니아와 투명 시멘트를 사용했을 때 색상일치를 잘 얻을 수 있다 는 저자의 이전 연구 ${ }^{39}$ 와 유사한 결과라고 할 수 있다.

한편 치과용 시멘트가 최종수복물의 색조에 미치는 영 향이 작거나 거의 없다는 실험결과도 존재한다. 이전 연 구들이 디스크 모양의 시편을 이용했던 것과는 달리 치 관형태의 지르코니아 시편을 제작하여 ${ }^{40} \mathrm{~A} 3$ 레진시멘트 와 투명 시멘트가 최종색상에 미치는 영향을 평가한 실 험에서 치과용 시멘트 색상은 최종색조에 영향을 주지 않았으며 시멘트의 존재유무도 색에 유의한 영향을 주지 않았다고 하였다.

이렇듯 배경의 유무 및 시편의 형태에 따라서 실험결가 달라질 수 있으므로 실험은 최대한 임상상황과 유사하게 이루어져야 한다. 정리하면 고반투명 지르코니아에서는 유색 시멘트를 사용하여 차폐효과를 기대하는 것이 유리 하며 저반투명 지르코니아에서는 투명 시멘트를 사용하 는 것이 보다 적절하다고 여겨진다.

\section{결론}

지르코니아 보철물 제작과정 중 색상에 영향을 미칠 수 있는 요인으로는 이트리아 함량, 두께, 소결과정, 연마 및 광택소성 그리고 치과용 시멘트 등이 있다. 이 가운데 이트리아 농도의 증가는 반투명도의 개선과 동시에 차폐 효과의 감소를 유발하여 의도했던 색상과의 색차이가 증 가할 수 있어 주의를 기울여야 한다. 수복물 두께가 증가 할수록 반투명도는 낮아지지만 적절한 차폐효과를 위해 
서는 일정 수준 이상의 두께가 필요하므로 충분한 치아 삭제 또는 수복공간 확보가 전제되어야 한다. 고속소결 방식은 지르코니아 보철물의 제작시간을 단축시킬 수 있 으나 지르코니아 블록의 물성에 따라 반투명도가 감소 하는 경우가 있어 제조사의 권고사항에 따라야 한다. 거 친 지르코니아의 표면은 난반사를 비롯한 광학적 성질 에 영향을 미칠 수 있으므로 연마 및 광택소성 과정에서 의 주의가 필요하다. 또한 적절한 유색 시멘트의 사용은 변색된 배경에서 적절한 차폐효과를 얻는데 도움이 되므 로 최종색상을 구현하는데 유용하다. 이상과 같이 다양 한 요소들이 유기적으로 지르코니아 보철물의 최종색조 에 영향을 미칠 수 있으므로 각각의 요소를 잘 고려하여 지르코니아 수복을 하는 것이 필요하다.

\section{ORCID}

Chan-Ho Park https://orcid.org/0000-0001-6892-7038 Kyung-Ho Ko https://orcid.org/0000-0002-1260-8844 Chan-Jin Park https://orcid.org/0000-0003-4734-214X Lee-Ra Cho https://orcid.org/0000-0003-3989-2870

Yoon-Hyuk Huh https://orcid.org/0000-0003-4072-5199

\section{References}

1. Denry I, Kelly JR. State of the art of zirconia for dental applications. Dent Mater 2008;24:299-307.

2. Tong H, Tanaka CB, Kaizer MR, Zhang Y. Characterization of three commercial Y-TZP ceramics produced for their high-translucency, high-strength and high-surface area. Ceram Int 2016;42:1077-85.

3. Zhang Y, Lawn BR. Novel Zirconia Materials in Dentistry. J Dent Res 2018;97:140-7.

4. Burgess JO. Zirconia: The Material, Its Evolution, and Composition. Compend Contin Educ Dent 2018;39:4-8.

5. Tabatabaian F. Color Aspect of Monolithic Zirconia Restorations: A Review of the Literature. J Prosthodont 2019;28:276-87.

6. Pekkan G, Ozcan M, Subasi MG. Clinical factors affecting the translucency of monolithic Y-TZP ceramics. Odontology 2020;108:526-31.

7. Salas M, Lucena C, Herrera LJ, Yebra A, Bona AD, Perez MM. Translucency thresholds for dental ma- terials. Dent Mater 2018;34:1168-74.

8. Yu B, Ahn JS, Lee YK. Measurement of translucency of tooth enamel and dentin. Acta Odontol Scand 2009;67:57-64.

9. Vichi A, Ferrari M, Davidson CL. Color and opacity variations in three different resin-based composite products after water aging. Dent Mater 2004;20:530-4.

10. Harada K, Raigrodski AJ, Chung KH, Flinn BD, Dogan S, Mancl LA. A comparative evaluation of the translucency of zirconias and lithium disilicate for monolithic restorations. J Prosthet Dent 2016;116:257-63.

11. Baldissara P, Wandscher VF, Marchionatti AME, Parisi C, Manaco C, Ciocca L. Translucency of IPS e.max and cubic zirconia monolithic crowns. J Prosthet Dent 2018;120:269-75.

12. Paravina RD, Ghinea R, Herrera LJ, Bona AD, Igiel C, Linninger M, Sakai M, Takahashi H, Tashkandi E, del Mar Perez M. Color difference thresholds in dentistry. J Esthet Restor Dent 2015;27:S1-9.

13. Sen N, Isler S. Microstructural, physical, and optical characterization of high-translucency zirconia ceramics. J Prosthet Dent 2020;123:761-8.

14. Cho YE, Lim YJ, Han JS, Yeo IL, Yoon HI. Effect of Yttria Content on the Translucency and Masking Ability of Yttria-Stabilized Tetragonal Zirconia Polycrystal. Materials (Basel) 2020;13:4726.

15. Kim HK. Optical and Mechanical Properties of Highly Translucent Dental Zirconia. Materials (Basel) 2020;13:3395.

16. Nakamura K, Harada A, Inagaki R, Kanno T, Niwano Y, Milleding P, Örtengren U. Fracture resistance of monolithic zirconia molar crowns with reduced thickness. Acta Odontol Scand 2015;73:602-8.

17. Tabatabaian F, Motamedi E, Sahabi M, Torabzadeh H, Namdari M. Effect of thickness of monolithic zirconia ceramic on final color. J Prosthet Dent 2018;120:257-62.

18. Tabatabaian F, Karimi M, Namdari M. Color match of high translucency monolithic zirconia restorations with different thicknesses and backgrounds. J Esthet Restor Dent 2020;32:615-21.

19. Kang CM, Peng TY, Shimoe S. Color accuracy of different types of monolithic multilayer precolored 
zirconia ceramics. J Prosthet Dent 2020;124:789.e1-7.

20. Sulaiman TA, Abdulmajeed AA, Donovan TE, Ritter AV, Vallittu PK, Närhi TO, Lassila LV. Optical properties and light irradiance of monolithic zirconia at variable thicknesses. Dent Mater 2015;31:1180-7.

21. Wang F, Takahashi H, Iwasaki N. Translucency of dental ceramics with different thicknesses. J Prosthet Dent 2013;110:14-20.

22. Juntavee N, Attashu S. Effect of sintering process on color parameters of nano-sized yttria partially stabilized tetragonal monolithic zirconia. J Clin Exp Dent 2018;10:e794-804.

23. Sanal FA, Kilinc H. Effect of shade and sintering temperature on the translucency parameter of a novel multi-layered monolithic zirconia in different thicknesses. J Esthet Restor Dent 2020;32:607-14.

24. Lawson NC, Maharishi A. Strength and translucency of zirconia after high-speed sintering. J Esthet Restor Dent 2020;32:219-25.

25. Jansen JU, Lumkemann N, Letz I, Pfefferle R, Sener B, Stawarczyk B. Impact of high-speed sintering on translucency, phase content, grain sizes, and flexural strength of 3Y-TZP and 4Y-TZP zirconia materials. J Prosthet Dent 2019;122:396-403.

26. Zhang Y. Making yttria-stabilized tetragonal zirconia translucent. Dent Mater 2014;30:1195-203.

27. Motro PF, Kursoglu P, Kazazoglu E. Effects of different surface treatments on stainability of ceramics. J Prosthet Dent 2012;108:231-7.

28. Alraheam IA, Donovan TE, Rodgers B, Boushell L, Sulaiman TA. Effect of masticatory simulation on the translucency of different types of dental zirconia. J Prosthet Dent 2019;122:404-9.

29. Manziuc MM, Gasparik C, Burde AV, Colosi HA, Negucioiu M, Dudea D. Effect of glazing on translucency, color, and surface roughness of monolithic zirconia materials. J Esthet Restor Dent 2019;31: 478-85.

30. Manziuc MM, Gasparik C, Burde AV, Dudea D. Color and masking properties of translucent monolithic zirconia before and after glazing. J Prosthodont Res 2021;65:303-10.

31. Saker S, Özcan M. Effect of surface finishing and polishing procedures on color properties and trans- lucency of monolithic zirconia restorations at varying thickness. J Esthet Restor Dent 2021;33:953-63.

32. Kim HK, Kim SH, Lee JB, Han JS, Yeo IS. Effect of polishing and glazing on the color and spectral distribution of monolithic zirconia. J Adv Prosthodont 2013;5:296-304.

33. Huh YH, Yang EC, Park CJ, Cho LR. In vitro evaluation of the polishing effect and optical properties of monolithic zirconia. J Prosthet Dent 2018;119: 994-9.

34. Lee YK, Lim BS, Kim CW. Influence of illuminating and viewing aperture size on the color of dental resin composites. Dent Mater 2004;20:116-23.

35. Özcan M, Bernasconi M. Adhesion to zirconia used for dental restorations: a systematic review and meta-analysis. J Adhes Dent 2015;17:7-26.

36. Malkondu O, Tinastepe N, Kazazoglu E. Influence of type of cement on the color and translucency of monolithic zirconia. J Prosthet Dent 2016;116:9028.

37. Bayindir F, Koseoglu M. The effect of restoration thickness and resin cement shade on the color and translucency of a high-translucency monolithic zirconia. J Prosthet Dent 2020;123:149-54.

38. Tabatabaian F, Khaledi Z, Namdari M. Effect of Ceramic Thickness and Cement Type on the Color Match of High-Translucency Monolithic Zirconia Restorations. Int J Prosthodont 2021;34:334-40.

39. Tabatabaian F, Habib Khodaei M, Namdari M, Mahshid M. Effect of cement type on the color attributes of a zirconia ceramic. J Adv Prosthodont 2016;8:449-56.

40. Ayash G, Osman E, Segaan L, Rayyan M, Joukhadar C. Influence of resin cement shade on the color and translucency of zirconia crowns. J Clin Exp Dent 2020;12:e257-63. 


\section{치과용 지르코니아의 광학적 성질에 영향을 미치는 요소에 대한 문헌고찰}

박찬호 대학원생, 고경호 부교수, 박찬진 교수, 조리라 교수, 허윤혁* 부교수

강릉원주대학교 치과대학 치과보철학교실 및 구강과학연구소

기존의 $3 \mathrm{~mol} \%$ 의 이트라아 $\left(\mathrm{Y}_{2} \mathrm{O}_{3}\right)$ 로 안정화된 정방정 지르코니아 $(3 \mathrm{~mol} \%$ yttria stabilized tetragonal zirconia polycrystal, $3 \mathrm{Y}-\mathrm{TZP}$ ) 뿐만 아니라 이트리아 함량이 증가된 반투명 지르코니아(translucent zirconia)를 이용한 단일구조 지르코 니아 보철물의 사용이 증가하면서 치과용 지르코니아의 광학적 성질에 영향을 미치는 요소에 대한 연구가 지속적으로 이루어지고 있다. 이트리아 함량, 보철물 두께, 소결과정, 연마 및 광택소성 그리고 치과용 시멘트 등과 같은 치과기공실 및 진료실 과정의 처리 방법에 따라 치과용 지르코니아의 광학적 효과가 다르게 나타난다. 이트리아 농도의 증가는 반투 명도의 개선과 동시에 차폐효과의 감소를 유발할 수 있으며 수복물 두께가 증가할수록 반투명도는 감소하지만 지르코 니아 블록의 물성에 따라 요구되는 두께가 다르므로 주의해야 한다. 고속소결 방식은 제작시간을 단축시키나 경우에 따 라 보철물의 반투명도가 감소할 수 있다. 지르코니아의 표면거칠기 및 광택소성 처리에 따라 광학적 결과도 영향을 받을 수 있다. 적절한 유색 시멘트의 사용은 지르코니아의 차폐효과에 도움이 되어 보다 자연스러운 보철치료가 가능하다.

(구강회복응용과학지 2021;37(4):177-85)

주요어: 지르코니아; 반투명도; 이트리아; 소결; 광택소성; 연마

*교신저자: 허윤혁

(25457) 강원도 강릉시 죽헌길 7 강릉원주대학교 치과대학 치과보철학교실

Tel: 033-640-2758 | Fax: 033-640-3103 | E-mail: vino@gwnu.ac.kr

접수일: 2021년 10월 18일 | 수정일: 2021년 10월 25일 | 채택일: 2021년 10월 27일 